Article

\title{
Easily prepared water soluble Pd-NHC complex as an efficient, phosphine-free palladium catalyst for the Sonogashira reaction
}

\author{
Chunyan Zhang a,b, Jianhua Liu a,*, Chungu Xia a,\# \\ a State Key Laboratory for Oxo Synthesis and Selective Oxidation, Lanzhou Institute of Chemical Physics, Chinese Academy of Sciences, Lanzhou 730000, \\ Gansu, China \\ b University of Chinese Academy of Sciences, Beijing 100039, China
}

\section{A R T I C L E I N F O}

Article history:

Received 23 February 2015

Accepted 9 March 2015

Published 20 August 2015

Keywords:

Pd-NHC complex

Sonogashira reaction

Water

Aryl iodide

Terminal alkyne

\section{A B S T R A C T}

A water soluble Pd-NHC complex was prepared and its catalytic activity in the Sonogashira reaction of terminal alkynes and aryl iodides using water as solvent under phosphine-free conditions was shown. This gives an efficient approach to diarylalkynes. The water soluble Pd-NHC complex can be easily recovered by extraction of the reaction solution and it was reused four times with only a slight loss of catalytic activity.

(C) 2015, Dalian Institute of Chemical Physics, Chinese Academy of Sciences. Published by Elsevier B.V. All rights reserved.

\section{Introduction}

Alkynes are of interest to material, pharmacentical and synthetic chemists since this functional group is one of the main building blocks of organic and material chemistry [1]. In addition, alkynes are also versatile building blocks in the synthesis of natural products, and pharmaceutical and agricultural chemicals [2-4]. Therefore, the practical and green synthesis of alkynes from simple starting materials is important for the fine chemical industries. The Sonogashira reaction is a powerful tool for the synthesis of these compounds [5-8]. Since its invention, much attention has been focused on the development of its efficient and selective palladium catalytic systems [9-11]. Although much progress has been achieved for the Sonogashira reaction, there are still many drawbacks in the current procedures, such as harsh reaction conditions, use of ecologically suspect organic solvents, long reaction time, and the use of transition metal catalysts. The development of new, efficient, practical and reusable catalytic systems and using water instead of an organic solvent are attractive for the Sonogashira reaction. Recently, some supported heterogeneous palladium catalytic systems were successfully achieved for the Sonogashira reaction in neat water $[12,13]$. Another attractive approach is to use a water soluble catalyst and water as the sole solvent, with the catalyst easily recovered by simple extraction and recycled [14-16].

Recently, Plenio's group [17,18], using sulfonated water-soluble ligands and complexes as catalyst were successful with some cross-coupling reactions with water as the solvent. Inspired by these results and in connection with our interests in the development of a new Pd-NHC (NHC:

\footnotetext{
* Corresponding author. Tel: +86-931-4968058; Fax: +86-931-8277088; E-mail: jhliu@licp.cas.cn

\# Corresponding author. Tel: +86-931-4968089; Fax: +86-931-8277088; E-mail: cgxia@licp.cas.cn

This work was supported by the National Natural Science Foundation of China (21373248 and 21133011).

DOI: 10.1016/S1872-2067(15)60843-9 | http://www.sciencedirect.com/science/journal/18722067 | Chin. J. Catal., Vol. 36, No. 8, August 2015
} 


$$
\mathrm{R}^{1} \rightleftharpoons+\mathrm{R}^{2}-\mathrm{I} \frac{\mathrm{Pd}-\mathrm{NHC}}{\mathrm{H}_{2} \mathrm{O}} \mathrm{R}^{1} \rightleftharpoons \mathrm{R}^{2}
$$

Scheme 1. Water soluble Pd-NHC catalyst for the Sonogashira reaction.

$\mathrm{N}$-Heterocyclic Carbene) catalytic system for the cross coupling $[16,19-24]$, we here describe a water soluble phosphine-free $\mathrm{Pd}-\mathrm{NHC} / \mathrm{H}_{2} \mathrm{O}$ catalytic system that is efficient for the Sonogashira coupling reaction of alkynes and aryl iodides (Scheme 1). It gave a series of diarylalkynes in one-pot synthesis under mild conditions. Notably, the isolation of the products was readily achieved by extraction with diethyl ether, and the Pd-NHC can be easily recycled and was reused four times with only a slight loss of catalytic activity.

\section{Experimental}

Synthesis and characterization of sIPr-Pd-Allyl-Cl. The sulfonated 2,6-diisopropylaniline (b) was synthesized in multi-steps from the known 2,6-diisopropylaniline (a) (Scheme 2). The conversion of $\mathbf{b}$ to sulfonated imine (c) by condensation was achieved in good yield using a slight of $\mathrm{HCOOH}$ as catalyst. In the next step, the desired 2,6-diisopropyl-sulfonated NHC (d) was prepared utilizing the route reported previously [17] The reaction of the sulfonated $\mathrm{NHC}$ (d) with [Pd(allyl)Cl] 2 in the presence of the base resulted in the formation of the corresponding sIPr-Pd-Allyl-Cl complex (e) (75\% yield) as reported in the related literature procedure [18].

${ }^{1} \mathrm{H}$ NMR (400 MHz, DMSO-d $): \delta=1.13-1.15(\mathrm{~m}, 12 \mathrm{H})$, 1.23-1.25 (m, 12H), 2.87-2.90 (m, 4H), 2.91-3.22 (m, 5H) 3.94-4.01 (m, 1H), $7.43(\mathrm{~s}, 4 \mathrm{H}), 7.65(\mathrm{~s}, 2 \mathrm{H})$.

${ }^{13} \mathrm{C}$ NMR (100 MHz, DMSO-d 6 ): $\delta=23.7,24.8,27.5,29.2$, $39.9,40.3,49.2,55.8,70.4,113.9,120.6,124.7,126.8,129.9$, 132.2, 141.7, 144.3, 145.0, 148.9, 182.7.

HRMS (ESI): calcd. for $\mathrm{C}_{30} \mathrm{H}_{39} \mathrm{ClN}_{2} \mathrm{Na}_{2} \mathrm{O}_{6} \mathrm{PdS}_{2} \quad[\mathrm{M}+\mathrm{Na}]^{+}$ 797.0666; found 797.1400.

\section{Results and discussion}

As an initial attempt, the reaction between 1a and $\mathbf{2 a}$ in water was chosen as the model reaction for the optimization of the Pd-catalyzed Sonogashira reaction conditions using sIPr-Pd-Allyl-Cl as a water soluble phosphine-free palladium-NHC catalyst (Table 1). 3aa was obtained in 34\% isolated yield in the presence of sIPr-Pd-Allyl-Cl with $\mathrm{K}_{2} \mathrm{CO}_{3}$ in water at
Table 1

Screening of reaction conditions.

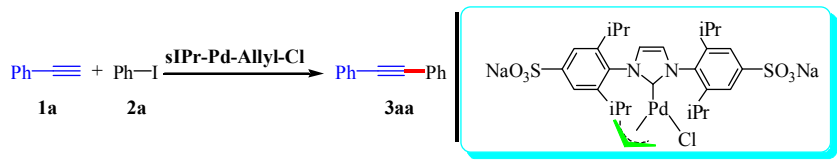

\begin{tabular}{lccc}
\hline Entry & Base & Solvent & Isolated yield (\%) \\
\hline 1 & $\mathrm{~K}_{2} \mathrm{CO}_{3}(2 \mathrm{~mol})$ & $\mathrm{H}_{2} \mathrm{O}$ & 34 \\
2 & $\mathrm{~K}_{3} \mathrm{PO}_{4}(2 \mathrm{~mol})$ & $\mathrm{H}_{2} \mathrm{O}$ & $<5$ \\
3 & $\mathrm{NaHCO}_{3}(2 \mathrm{~mol})$ & $\mathrm{H}_{2} \mathrm{O}$ & $<5$ \\
4 & $\mathrm{NaOH}_{2}(2 \mathrm{~mol})$ & $\mathrm{H}_{2} \mathrm{O}$ & $<5$ \\
5 & $\mathrm{NaOMe}(2 \mathrm{~mol})$ & $\mathrm{H}_{2} \mathrm{O}$ & $<5$ \\
6 & $\mathrm{KOtBu}(2 \mathrm{~mol})$ & $\mathrm{H}_{2} \mathrm{O}$ & 59 \\
7 & $\mathrm{NaOAc}(2 \mathrm{~mol})$ & $\mathrm{H}_{2} \mathrm{O}$ & $<5$ \\
8 & $\mathrm{DBU}(2 \mathrm{~mol})$ & $\mathrm{H}_{2} \mathrm{O}$ & 21 \\
9 & $\mathrm{Et}{ }_{3} \mathrm{~N}(0.5 \mathrm{~mL})$ & $\mathrm{H}_{2} \mathrm{O}$ & 93 \\
10 & $\mathrm{Et}_{3} \mathrm{~N}(0.5 \mathrm{~mL})$ & $\mathrm{DMF}_{1}$ & 31 \\
11 & $\mathrm{Et}_{3} \mathrm{~N}(0.5 \mathrm{~mL})$ & $1,4-d i o x a n e$ & $<5$ \\
12 & $\mathrm{Et}_{3} \mathrm{~N}(0.5 \mathrm{~mL})$ & $\mathrm{THF}$ & 49 \\
13 & $\mathrm{Et}_{3} \mathrm{~N}(0.5 \mathrm{~mL})$ & $\mathrm{Et} 2 \mathrm{O}$ & $<5$ \\
14 & $\mathrm{Et}_{3} \mathrm{~N}(0.5 \mathrm{~mL})$ & $\mathrm{CH}_{3} \mathrm{CN}$ & 85 \\
15 & $\mathrm{Et}_{3} \mathrm{~N}(0.5 \mathrm{~mL})$ & $\mathrm{MeOH}$ & 27 \\
\hline
\end{tabular}

Reaction conditions: 1a (1.0 mmol), 2a (2.0 mmol), sIPr-Pd-Allyl-Cl (0.5 mol \%), solvent $(2.0 \mathrm{~mL}), 60^{\circ} \mathrm{C}, 6 \mathrm{~h}$.

$60{ }^{\circ} \mathrm{C}$ for 6 hours (Table 1, entry 1). This result indicated that our cross coupling reaction between $\mathbf{1 a}$ and $\mathbf{2 a}$ was indeed possible. We next examined the optimal bases. The best result was obtained with the participation of $\mathrm{Et}_{3} \mathrm{~N}$. Other inorganic bases such as $\mathrm{K}_{3} \mathrm{PO}_{4}, \mathrm{NaHCO}_{3}, \mathrm{NaOH}$, and organic bases, such as $\mathrm{NaOMe}, \mathrm{KO}^{t} \mathrm{Bu}, \mathrm{NaOAc}$ and $\mathrm{DBU}$ in this Sonogashira reaction gave slightly lower yields under the same reaction conditions (Table 1, entries 2-8). Meanwhile, the reaction in other solvents, polar aprotic solvents (DMF), worked for the synthesis of 3aa, producing the coupling product in 31\% yield (Table 1, entry 10). No appreciable increase in yield was obtained with other solvents, such as 1,4-dioxane, THF, $\mathrm{Et}_{2} \mathrm{O}, \mathrm{CH}_{3} \mathrm{CN}$ and $\mathrm{EtOH}$ (Table 1, entries 11-15). Finally, the control reaction in the absence of sIPr-Pd-Allyl-Cl and base failed to give the desired product in high yield, indicating that the palladium catalyst and base were crucial to this Sonogashira coupling reaction. More important, this transformation is very practical as phosphine is not required and the water soluble NHC-Pd catalyst loading was only $0.5 \mathrm{~mol} \%$ with water as solvent.

With these results in hand, we next investigated the substrate scope of this Sonogashira reaction. As shown in Table 2,
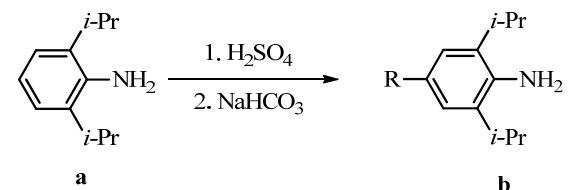

b

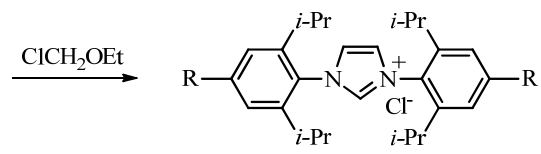

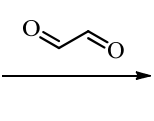
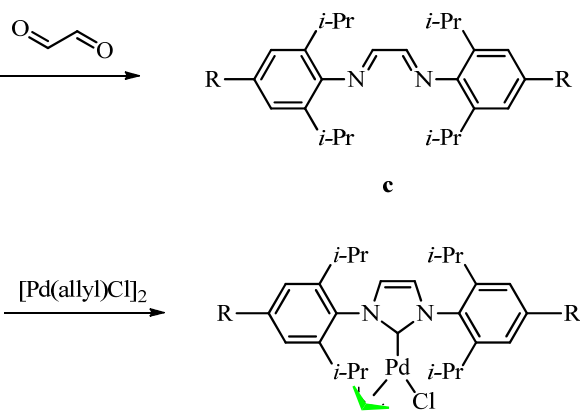

e: $\mathrm{R}=\mathrm{SO}_{3} \mathrm{Na}$, sIPr-Pd-Allyl-Cl

Scheme 2. Synthesis of the Pd-NHC complex 
Table 2

Substrate scope of alkynes.

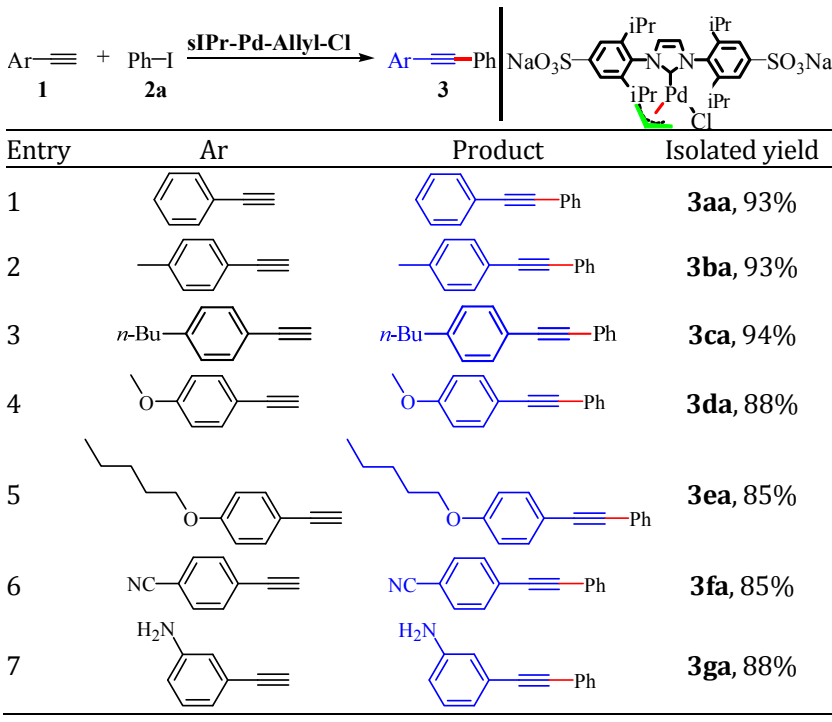

General conditions: $\mathbf{1}(1.0 \mathrm{mmol}), \mathbf{2 a}(2.0 \mathrm{mmol})$, sIPr-Pd-Allyl-Cl $(0.5$ $\mathrm{mol} \%), \mathrm{Et}_{3} \mathrm{~N}(0.5 \mathrm{~mL}), \mathrm{H}_{2} \mathrm{O}(2.0 \mathrm{~mL}), 60^{\circ} \mathrm{C}, 6 \mathrm{~h}$.

for alkynes, a series of functional groups, such as methyl, $n$-butyl, methoxy, $n$-pentoxyl cyano and amino contained in the phenyl-ring were compatible with the present $\mathrm{Pd}-\mathrm{NHC} / \mathrm{H}_{2} \mathrm{O}$ catalytic system. The desired products were excellent in isolated yields (3aa-3ga), which indicated that the present reaction has good functional group tolerance. In general, electron-donating and electron-withdrawing groups contained in the phenyl ring were tolerated well, giving the corresponding products in $85 \%-94 \%$. Furthermore, when 4-ethynylbenzonitrile was subjected to this procedure, $85 \%$ yield was isolated. It is worth noting that the tolerance of the cyano group on the aromatic ring in this protocol offers an opportunity for subsequent transformations, which facilitates the expedient synthesis of diarylalkynes. In addition, the challenging 3-ethynylaniline $1 \mathrm{~g}$ successfully underwent this reaction to provide the desired product 3ga in $88 \%$ yield.

As summarized in Table 3, the Sonogashira reaction catalyzed by the complex sIPr-Pd-allyl-Cl was found to be general

Table 3

Substrate Scope of Aryl Iodides.

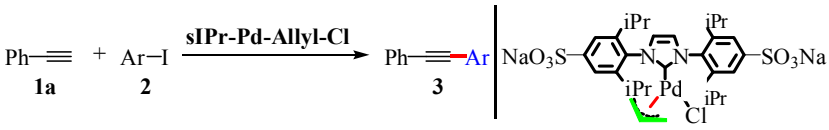

\begin{tabular}{llll}
\hline Entry & Isolated yield \\
\hline
\end{tabular}

General conditions: 1a (1.0 mmol), $2(2.0 \mathrm{mmol})$, sIPr-Pd-Allyl-Cl $(0.5$ $\mathrm{mol} \%), \mathrm{Et}_{3} \mathrm{~N}(0.5 \mathrm{~mL}), \mathrm{H}_{2} \mathrm{O}(2.0 \mathrm{~mL}), 60^{\circ} \mathrm{C}, 6 \mathrm{~h}$.

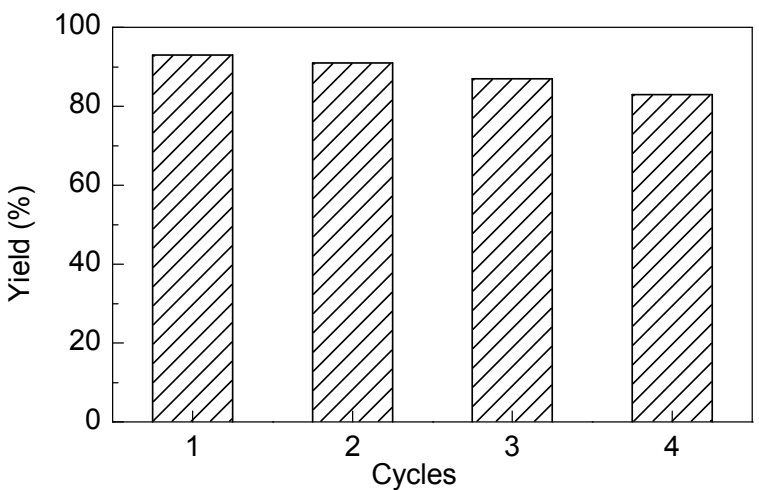

Fig. 1. Recyclability of the sIPr-Pd-Allyl-Cl catalyst in the Sonogashira reaction of iodobenzene with phenyl acetylene

with aryl iodides bearing a variety of substituents. Aryl iodides containing various electron-rich and electron-deficient functional groups reacted smoothly to give the corresponding products in high yields (3aa-3ae). Typical functional groups, such as methyl, methoxyl and halide groups, were compatible with the reaction conditions. Notably, the free phenolic hydroxyl group, 4-iodophenol, was also suitable for this reaction, affording the corresponding product 3ae in good yield under the standard conditions.

To examine the recyclability of our water soluble Pd-NHC catalyst with a lower catalyst loading, the reuse investigation was performed with the model Sonogashira reaction of 1a with 2a and sIPr-Pd-Allyl-Cl for $6 \mathrm{~h}$ at $60^{\circ} \mathrm{C}$. After the completion of reaction, ether was added to the reaction tube, and the upper organic phase containing the product was easily separated by simple liquid-liquid extraction to produce 3aa. The residual aqueous catalyst phase remained because of the obvious solubility difference of the $\mathrm{SO}_{3} \mathrm{Na}$ salt functionalized sIPr-Pd-Allyl-Cl in ether and water and was reused for the next run. It is shown in Fig. 1 that our water soluble catalyst can be used at least four times with the fourth run giving $83 \%$ isolated yield of 3aa.

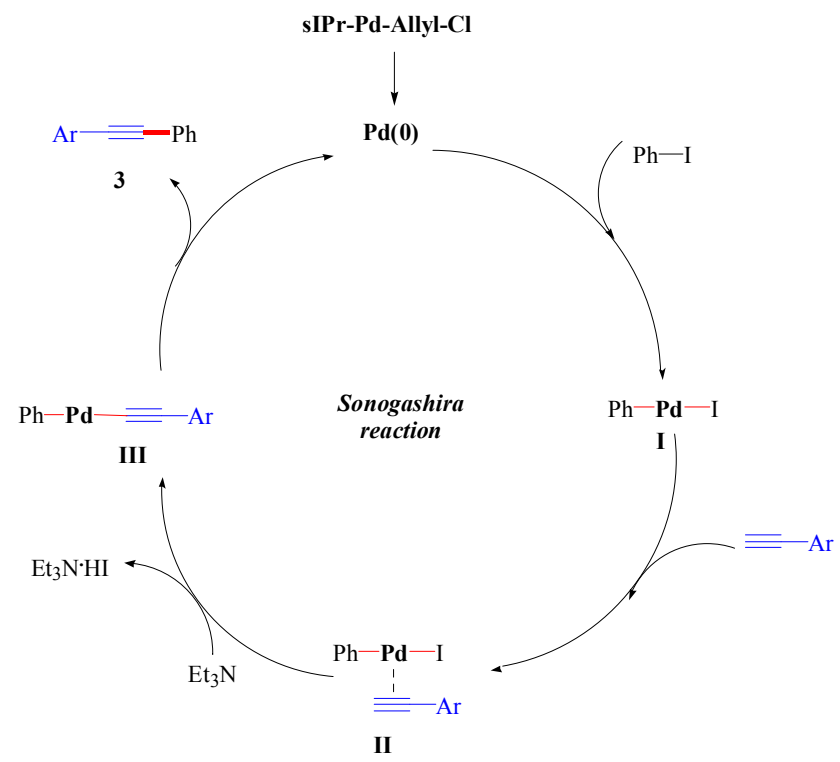

Scheme 3. Plausible reaction mechanism. 


\title{
Graphical Abstract
}

Chin. J. Catal., 2015, 36: 1387-1391 doi: 10.1016/S1872-2067(15)60834-9

Easily prepared water soluble Pd-NHC complex as an efficient, phosphine-free palladium catalyst for the Sonogashira reaction

Chunyan Zhang, Jianhua Liu*, Chungu Xia*

Lanzhou Institute of Chemical Physics, Chinese Academy of Sciences; University of Chinese Academy of Sciences

A water soluble Pd-NHC complex was prepared and its catalytic activity in the Sonogashira reaction of terminal alkynes and aryl iodides using water as solvent under phosphine-free conditions was shown. This gives an efficient approach to diarylalkynes. The water soluble Pd-NHC complex can be easily recovered by extraction of the reaction solution and it was reused four times with only a slight loss of catalytic activity.
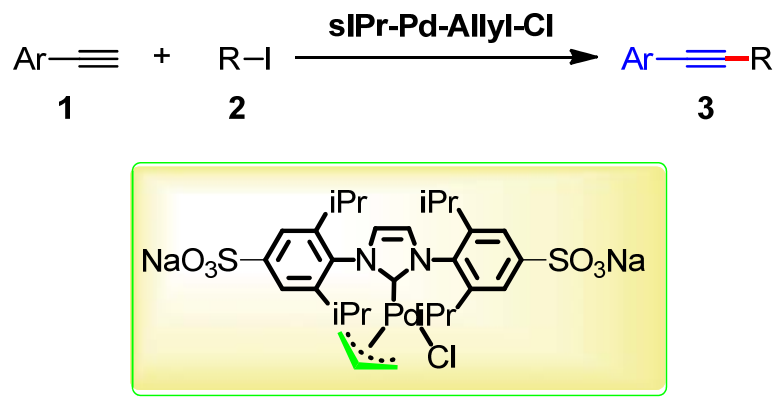

A reaction mechanism for the Sonogashira reaction is shown in Scheme 3. Initial oxidative addition of aryl iodide to $\operatorname{Pd}(0)$ provides arylpalladium complex I, which was formed in situ from the reduction of the catalyst precursor of Pd-NHC $[25,26]$. Because of a tightly bound NHC as the resting ligand, the active species was stabilized during catalysis. Subsequent coordination of a terminal alkyne to the complex I and alkyne insertion into the carbon-palladium bond generated complex III in the presence of a base. Finally, reductive elimination from complex III gave product $\mathbf{3}$ and the active $\mathrm{Pd}(0)$ for the next catalytic cycle.

\section{Conclusions}

We disclosed an efficient and facile water soluble phosphine-free Pd-NHC catalytic system for the direct formation of a range of diarylalkynes from commercially available alkynes and aryl iodides using the Sonogashira reaction under mild conditions. A water soluble Pd-NHC complex was prepared and its catalytic activity in the Sonogashira reaction was examined. The Pd-NHC catalyst can be easily recycled and it was reused four times with only a slight loss of catalytic activity. Further investigation on the application of the water soluble Pd-NHC catalytic system in other carbonylation reactions are currently underway in our laboratory.

\section{References}

[1] Yin L X, Liebscher J. Chem Rev, 2007, 107: 133

[2] Haddad N, Tan J, Farina V. J Org Chem, 2006, 71: 5031

[3] Chinchilla R, Najera C. Chem Soc Rev, 2011, 40: 5084

[4] Bunz U H F. Chem Rev, 2000, 100: 1605
[5] Sonogashira K, Tohda Y, Hagihara N. Tetrahedron Lett, 1975, 16 : 4467

[6] Dieck H A, Heck F R. J Organomet Chem, 1975, 93: 259

[7] Cassar L.J Organomet Chem, 1975, 93: 253

[8] Bakherad M, Keivanloo A, Samangooei S. Chin J Catal (催化学报), 2014, 35: 324

[9] Ghent B L, Sites L A, Rheingold A L, Nataro C. Organometallics, 2005, 24: 4788

[10] Nazario C E D, Santana A S, Kawasoko C Y, Carollo C A, Hurtado G R, Viana L H, Barbosa S L, Guerrero P G, Marques F A, Dabdoub V B, Dabdoub M J, Baroni A C M, Tetrahedron Lett, 2011, 52: 4177

[11] Bhattacharya S, Sengupta S. Tetrahedron Lett, 2004, 45: 8733

[12] Hajipour A R, Shirdashtzade Z, Azizi G. App Organomet Chem, 2014, 28: 696

[13] Hajipour A R. Azizi G. RSC Adv, 2014, 4: 20704

[14] Pierre Genet J, Savignac M. J Organomet Chem, 1999, 576: 305

[15] Firouzabadi H, Iranpoor N, Gholinejad M. J Mol Catal A, 2010, 321: 110

[16] Wang Y, Liu J H, Xia C G. Tetrahedron Lett, 2011, 52: 1587

[17] Fleckenstein C, Roy S, Leuthäusser S, Plenio H. Chem Commun, 2007, 2870

[18] Roy S, Plenio H. Adv Synth Catal, 2010, 352: 1014

[19] Zheng S Z, Peng X G, Liu J M, Sun W, Xia C G. Chin J Chem (中国化 学), 2007, 25: 1065

[20] Zheng S Z, Li F W, Liu J M, Xia C G. Tetrahedron Lett, 2007, 48: 5883

[21] Zheng S Z, Wang Y, Zhang C Y, Liu J H, Xia C G. App Organomet Chem, 2014, 28: 48

[22] Liu J H, Chen J, Xia C G. J Catal, 2008, 253: 50

[23] Liu J M, Peng X G, Sun W, Zhao Y W, Xia C G. Org Lett, 2008, 10: 3933

[24] Zhang C Y, Liu J H, Xia C G. Org Biomol Chem, 2014, 12: 9702

[25] Izquierdo F, Corpet M, Nolan S P. Eur J Org Chem, 2015, (9): 1920

[26] Hruszkewycz D P, Balcells D, Guard L M, Hazari N, Tilset M. J Am Chem Soc, 2014, 136: 7300

\section{水溶性氮杂环卡宾钯金属配合物催化的Sonogashira反应}

\author{
张春艳 ${ }^{\mathrm{a}, \mathrm{b}}$, 刘建华 ${ }^{\mathrm{a},{ }^{*}}$, 夏春谷 ${ }^{\mathrm{a}, \#}$ \\ ${ }^{\mathrm{a}}$ 中国科学院兰州化学物理研究所羰基合成与选择氧化国家重点实验室, 甘肃兰州730000 \\ ${ }^{\mathrm{b}}$ 中国科学院大学, 北京 100049
}


摘要: 成功合成了一种磺酸钠基团官能团化的水溶性氮杂环卡宾钯金属配合物. 在无膦、以水作溶剂的反应条件下,这种水溶性 卡宾钯金属配合物能高效催化碘代芳烃和端基炔烃的Sonogashira偶联反应, 反应结束后, 可以通过萃取的方式把催化剂从反应混 合物中分离出来, 该催化剂可以重复循环使用四次.

关键词: 氮杂环卡宾钯金属配合物; Sonogashira反应; 水; 碘代芳烃; 端基炔烃

收稿日期: 2015-02-23. 接受日期: 2015-03-09. 出版日期: 2015-08-20.

“通讯联系人. 电话: (0931)4968058; 传真: (0931)8277088; 电子信箱: jhliu@licp.cas.cn

通讯联系人. 电话: (0931)4968089; 传真: (0931)8277088; 电子信箱: cgxia@licp.cas.cn

基金来源：国家自然科学基金(21373248和21133011).

本文的英文电子版由Elsevier出版社在ScienceDirect上出版(http://www.sciencedirect.com/science/journal/18722067). 